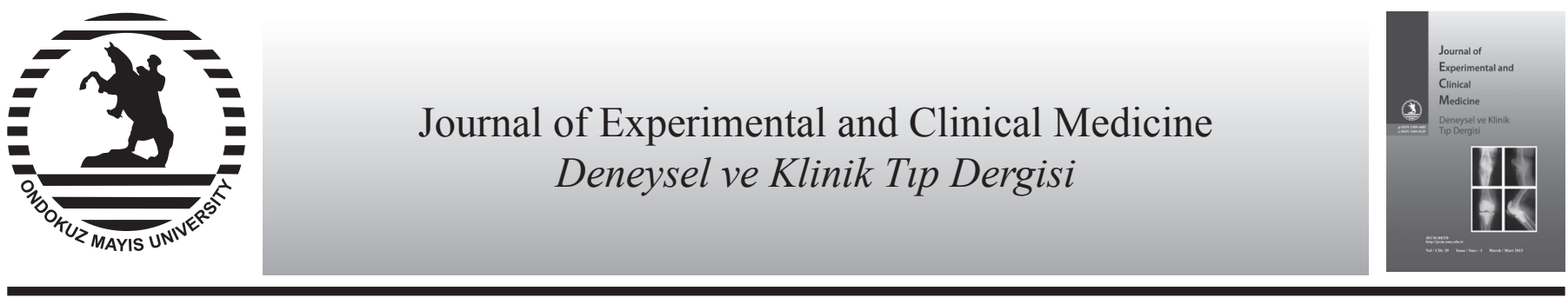

Experimental Research

doi: $10.5835 /$ jecm.omu.29.01.011

\title{
The effects of albendazole-alcohol solution on the hepatobiliary system
}

\author{
Güray Sarpa ${ }^{\text {, Ramazan Amanvermez*b }}{ }^{* \mathrm{~b}}$ Cafer Polat ${ }^{\mathrm{a}}$, Kenan Erzurumlua ${ }^{\mathrm{a}}$, Erol Kılıça, M.Yavuz Gülbahar \\ ${ }^{a}$ Department of Surgery, Medical Faculty, Ondokuz Mayls University, Samsun, Turkey \\ ${ }^{b}$ Department of Biochemistry, Medical Faculty, Ondokuz Mayls University, Samsun, Turkey \\ ${ }^{c}$ Department of Pathology, Veterinary Faculty, Ondokuz Mayls University, Samsun, Turkey
}

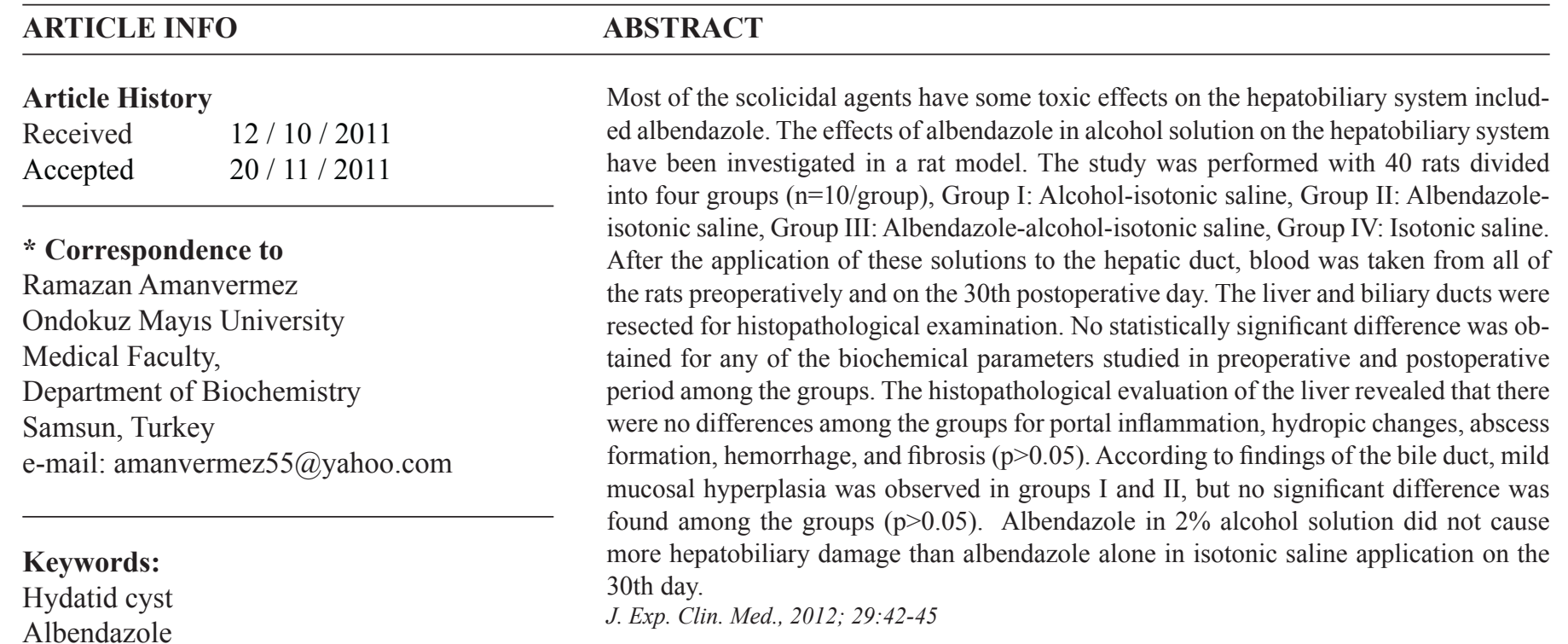

Albendazole

Sclerosing cholangitis

Scolicidal agent

C 2012 OMU All rights reserved

\section{Introduction}

Hydatid cyst disease is going to be an important health and economical problem for developing countries (Eckert et al., 1982). Echinococcal cysts may develop in all of organs but it forms in the liver and lung mostly in human. The principle treatment hydatid cyst disease is surgery, even though this disease could be treated medically. In addition, recent invasive radiological methods are commonly used for the treatment of hydatid cysts localized in the liver.

After surgical treatment, an important complication of hydatid cyst is secondary hydatidosis. This complication may be prevented by using effective scolicidal solutions and a meticulous surgical technique. Scolicidal agents such as formalin, ethyl alcohol, alcohol-iodine, povidone-iodine, hypertonic saline and albendazole have been used for the purpose of killing the living scolexes in cyst (Erzurumlu et al., 1990; Eyüpoğlu et al., 1999; Kozak et al., 2000). During the application of a scolicidal solution inside the cyst wall, solution may pass into the liver and biliary tract communicated with the cyst. Sclerosing cholangitis may occur as a result of the application of scolicidal agents (Karavias et al., 1996; Montera et al., 1996). This clinical phenomenon is also called "caustic sclerosing colangitis" by some authors (Aggarwal and Garg, 1983; Bilghiti et al., 1986). Sclerosing cholangitis is a chronic cholestatic disease characterized by inflammation, fibrosis, and stenosis of biliary ducts. The onset of scolicidal-induced sclerosing cholangitis is between one week and one year in humans (Sezer et al., 2010).

As a protoscolicidal agent, albendazole solution is the most appropriate treatment having the least adverse effects on the hepatobiliary system (Paksoy et al., 2005; Yetim et al., 2005). However, there is some trouble with the dissolving of albendazole in solvent. Completely, its solubility is difficult in saline. Albendazole is a lipophylic drug which can better dissolve in absolute alcohol. The aim of this study was to investigate the likely histopathological and biochemical effects of albendazole-alcohol-saline solution on the hepatobiliary system in a rat model. 


\section{Materials and methods}

This experimental study was carried out in Experimental Research Center, Ondokuz Mayıs University, Samsun / Turkey. Adult Wistar Albino rats weighing 340-410 g were used for this experimental research. The rats were kept in cages with wood chip bedding and fed on standard laboratory chow and water ad libitum. They were maintained on a $12 \mathrm{~h}$ light: dark cycle with a constant room temperature at $22 \pm 1^{\circ} \mathrm{C}$. The local ethical committee of Ondokuz Mayıs University approved all animal procedures, and the experimental protocol.

\section{Animal treatment}

Rats were randomly allocated into the following groups ( $n=10$ /group): Group I: Alcohol-isotonic saline, Group II: Albendazole-isotonic saline, Group III: Albendazole-alcohol-isotonic saline, Group IV: Isotonic saline $(0.9 \% \mathrm{NaCl})$ as control.

\section{Prepared solutions}

Albendazole was purchased from Biofarma Drug Company. In Group I, solution was prepared in $2 \mathrm{ml}$ absolute alcohol by adding $98 \mathrm{ml}$ saline. In Group II, $2 \mathrm{mg}$ albendazole was dissolved in $100 \mathrm{ml}$ saline. In Group III, $2 \mathrm{mg}$ albendazole was dissolved in $2 \mathrm{ml}$ absolute alcohol by heating slightly on magnetic mixture with temp (1kamag ${ }^{\circledR} \mathrm{rh}$, jonke and kunkel), and then $50 \mathrm{ml}$ saline added to this solution held on ultrasonic bathe during 45 minutes. Then, volume was completed to 100 $\mathrm{ml}$ by adding saline. In Group IV, only isotonic saline was used.

\section{Surgical Preparation}

During the last 12 hours before the experiments, the animals were allowed ad libitum access to water, but no solid food. In the morning, first blood sample was taken from rat tail prior to surgical operation. Each rat was fixed on operating table at supine position. The rats' abdomen was shaved and then the dermal antisepticity was provided with povidone-iodine. Then, the rats were anesthesized with an intraperitoneal administration of ketamine (50 mg/kg body weight) and $5 \mathrm{mg} /$ $\mathrm{kg}$ Xylazine (Rompon flk. Bayer). Anaesthesia was maintained by additional doses of ketamine, as required. All surgical procedures were performed under sterile conditions. A midline laparotomy was performed; the duodenum and the common bile duct were dissected and isolated. A 24 gauge catheter was introduced through ampulla vateri into the common bile duct transduodenally. The bile drainage from the catheter was observed. The experimental solutions or $0.2 \mathrm{ml}$ of saline of each group were injected into the common bile duct under low pressure within 30 seconds. After hemostasis, the peritoneum and the skin were closed separately by using continuous suture. After the application of solution in the groups, the rats were kept in cage and maintained on standard laboratory chow and water ad libitum during 30 days. Similar preoperative procedures were performed on the postoperative 30th day for each group; second blood sample was obtained by direct intra-cardiac puncture with an injector. All rats were sacrified by exsanguinations under anaesthesia at the end of experimental study. The main bile ducts, the porta hepatis and the liver of all the subjects were resected. The tissue samples were washed in isotonic sodium chloride solution, dried with filter paper and fixed in $10 \%$ buffered formaldehyde for histopathological examination. Sections from the common bile duct, the porta hepatis and the liver parenchyma were processed and embedded in paraffin. Tissue sections were stained by hematoxylin and eosine (HE) and cut into 4-6 $\mu \mathrm{m}$ thick and evaluated under light microscope (Nikon Eclipse E600) by a pathologist blind to the experimental procedures. Microscopic changes appeared in the liver and biliary ducts were noted and then defined by comparing the groups. The scoring of the histopathological changes of the liver was composed with respect to scoring system developed by Yetim et al. (2005). It was modified for the histopathologic scoring of bile duct (Table 1 and 2).

\begin{tabular}{|c|c|c|c|}
\hline Score & & Score & \\
\hline & Hydropic changes & & Fatty degeneration \\
\hline 0 & None & 0 & None \\
\hline 1 & $\begin{array}{l}\text { Focal (zonal and restricted } \\
\text { to few lobules) }\end{array}$ & 1 & Focal \\
\hline 2 & $\begin{array}{l}\text { Marked (zonal but in all } \\
\text { lobules) }\end{array}$ & 2 & Marked \\
\hline \multirow[t]{2}{*}{3} & $\begin{array}{l}\text { Widespread (all lobules and } \\
\text { all zones) }\end{array}$ & 3 & Widespread \\
\hline & Single cell necrosis & & Abscess formation \\
\hline 0 & None & 0 & Absent \\
\hline 1 & Few (few lobules) & 1 & Present \\
\hline \multirow[t]{2}{*}{2} & Widespread (all lobules) & & \\
\hline & Hemorrhage & & Hepatocellular necrosis \\
\hline 0 & Absent & 0 & None \\
\hline \multirow[t]{4}{*}{1} & Present (zonal) & 1 & $\begin{array}{l}\text { Focal (single focus in } \\
\text { single lobule) }\end{array}$ \\
\hline & & 2 & $\begin{array}{l}\text { Marked (single focus in } \\
\text { all lobules) }\end{array}$ \\
\hline & & 3 & Intense (all lobules) \\
\hline & Portal inflammation & & Fibrosis \\
\hline 0 & None & 0 & None \\
\hline 1 & $\begin{array}{l}\text { Rare (involves 1-2 portal } \\
\text { areas) }\end{array}$ & 1 & $\begin{array}{l}\text { Mild (fibrous portal } \\
\text { expansion) }\end{array}$ \\
\hline 2 & $\begin{array}{l}\text { Marked (involves }>2 \text { portal } \\
\text { areas) }\end{array}$ & 2 & Severe (zonal bridging) \\
\hline
\end{tabular}

Table 2. The histopathologic scoring of bile duct

\begin{tabular}{cccccc} 
Score & $\begin{array}{c}\text { Hydropic } \\
\text { changes }\end{array}$ & Score & $\begin{array}{c}\text { Mucosal } \\
\text { hyperplasia }\end{array}$ & Score & Inflammation \\
\hline 0 & None & 0 & None & 0 & None \\
1 & Mild & 1 & Mild & 1 & Mild \\
2 & Moderate & 2 & Moderate & 2 & Moderate \\
3 & Severe & 3 & Severe & 3 & Severe \\
\hline
\end{tabular}

Aspartate aminotransferase (AST), alanine aminotransferase (ALT), alkaline phosphatase (ALP), $\gamma$-glutamyl transferase (GGT), and total bilirubin levels in first and second blood samples were measured by a clinical chemistry laboratory. All biochemical data were checked for the normality of distribution by Shapiro-Wilk test. Those that had normal distribution were statistically evaluated by Tukey HSD test. Pvalues $<0.05$ were accepted to be statistically significant. Statistical differences were set at a $95 \%$ confidence interval. Non-normally distributed histopathologic score evaluations were analyzed by Kruskal-Wallis test and then group comparisons were performed by Bonferroni corrected Mann-Whitney U. Statistical 
significance was accepted at $\mathrm{p}<0.01$. Also, data median value and distribution of $25-75 \%$ were reported.

\section{Results}

The results of biochemical and histopathological findings were shown in Tables 3, 4, and 5. No statistically significant difference was found in any of the biochemical findings studied between the groups at the preoperative (at first serum) and post-operative serum of the rats (at 30th day serum) $(\mathrm{p}>0.05)$. No abnormal levels of AST and ALT were determined on postoperative 30th day in Groups II and III (Table 3). In the postoperative period, GGT was slightly higher in groups II and III compared to preoperative values in these groups. Data given as Mean $\pm \mathrm{SD}$

\begin{tabular}{|c|c|c|c|c|c|c|}
\hline \multicolumn{2}{|c|}{ Groups } & $\begin{array}{l}\text { AST } \\
(\mathrm{U} / \mathrm{L})\end{array}$ & $\begin{array}{c}\text { ALT } \\
(\mathrm{U} / \mathrm{L})\end{array}$ & $\begin{array}{l}\text { GGT } \\
(\mathrm{U} / \mathrm{L})\end{array}$ & $\begin{array}{c}\text { ALP } \\
(\mathrm{U} / \mathrm{L})\end{array}$ & $\begin{array}{c}\text { Total Bil } \\
\text { (mg/dl) }\end{array}$ \\
\hline \multirow[b]{2}{*}{ I } & Preoperative & $168.89 \pm 22.3$ & $98.22 \pm 14.8$ & $1.56 \pm 0.63$ & $501.56 \pm 48.37$ & $0.07 \pm 0.01$ \\
\hline & Postoperative & $137.80 \pm 14.1$ & $70.11 \pm 7.3$ & $1.76 \pm 0.55$ & $383 \pm 42.10$ & $0.04 \pm 0.01$ \\
\hline \multirow{2}{*}{ II } & Preoperative & $175.33 \pm 25.1$ & $77.33 \pm 16.2$ & $1.76 \pm 0.84$ & $451 \pm 26.23$ & $0.06 \pm 0.01$ \\
\hline & Post operative & $143.11 \pm 16.7$ & $62.44 \pm 8.1$ & $2.36 \pm 0.95$ & $364.89 \pm 32.46$ & $0.042 \pm 0.0$ \\
\hline \multirow{3}{*}{ III } & Preoperative & $144.70 \pm 21.1$ & $56.50 \pm 7.9$ & $1.34 \pm 0.53$ & $520.10 \pm 56.32$ & $0.04 \pm 0.00$ \\
\hline & Postoperative & $154.10 \pm 17.0$ & $57.60 \pm 5.1$ & $2.01 \pm 0.67$ & $308.60 \pm 51.76$ & $0.06 \pm 0.01$ \\
\hline & Preoperative & $155.44 \pm 12.3$ & $60.22 \pm 6.7$ & $2.67 \pm 0.82$ & $399.11 \pm 46.72$ & $0.03 \pm 0.00$ \\
\hline IV & Postoperative & $164.67 \pm 15.4$ & $61.33 \pm 7.1$ & $2.63 \pm 0.81$ & $402.00 \pm 47.52$ & $0.02 \pm 0.00$ \\
\hline
\end{tabular}

(AST); Aspartate aminotransferase, (ALT); Alanine aminotransferase, (ALP); Alkaline phosphatase, (GGT); $\gamma$-glutamyl transferase

The histopathological evaluation of the liver revealed that there were no differences among the groups for portal inflammation, hydropic changes, abscess formation, hemorrhage, and fibrosis ( $\mathrm{p}>0.05)$.

Single cell necrosis and hepatocellular necrosis were not observed in Group IV. However, there was no difference among Groups I, II and III ( $>0.05$ ) (Table 4).

\begin{tabular}{|c|c|c|c|c|}
\hline Groups & $\begin{array}{c}\text { Hydropic changes } \\
\text { (Med, } 25-75 \%)\end{array}$ & $\begin{array}{c}\text { Single cell } \\
\text { necrosis } \\
(\text { Med, 25-75\%) }\end{array}$ & $\begin{array}{c}\text { Hepatocellular } \\
\text { necrosis } \\
\text { (Med, 25-75\%) }\end{array}$ & $\begin{array}{c}\text { Portal } \\
\text { inflammation } \\
\text { (Med, 25-75\%) }\end{array}$ \\
\hline I & $2.0(2.0-3.0)$ & $1.0(1.0-1.0)$ & $1.0(1.0-1.0)$ & $2.0(1.0-2.0)$ \\
\hline II & $3.0(2.0-3.0)$ & $1.0(1.0-1.0)$ & $2.0(1.0-2.0)$ & $2.0(2.0-2.0)$ \\
\hline III & $3.0(2.0-2.25)$ & $1.0(1.0-1.0)$ & $1.0(1.0-1.25)$ & $2.0(2.0-2.0)$ \\
\hline IV & $2.0(1.5-3.0)$ & $0.0(0.0-0.0)$ & $0.0(0.0-0.0)$ & $2.0(1.5-2.5)$ \\
\hline
\end{tabular}

Table 5. Medians according to histopathological findings of bile duct in the groups

\begin{tabular}{cccc} 
Groups & $\begin{array}{c}\text { Mucosal } \\
\text { hyperplasia } \\
(\text { Med, 25 -75\%) }\end{array}$ & $\begin{array}{c}\text { Hidropic changes } \\
(\text { Med, 25 -75\%) }\end{array}$ & $\begin{array}{c}\text { Inflammation } \\
(\text { Med, 25 -75\%) }\end{array}$ \\
\hline I & $1.0(0.0-2.0)$ & $2.0(1.0-2.0)$ & $1.0(0.0-1.5)$ \\
II & $1.0(0.5-2.0)$ & $2.0(1.0-2.0)$ & $2.0(0.0-2.0)$ \\
III & $0.0(0.0-1.25)$ & $1.0(0.0-1.25)$ & $0.5(0.0-1.0)$ \\
IV & $0.0(0.0-1.0)$ & $0.0(0.0-0.5)$ & $0.0(0.0-0.0)$ \\
\hline
\end{tabular}

According to the histopathological findings of the bile duct, mild mucosal hyperplasia was observed in groups I and II, but no signicant difference was found among the groups $(p>0.05)$. In the tissue samples of the bile duct of groups I and II, some hydropic changes of the epithelium and periductal inflammation occurred, but these findings were observed at the least degree in the Group III (Table 5). In the Group IV, there was no significant finding in bile duct structures (Fig. 1).

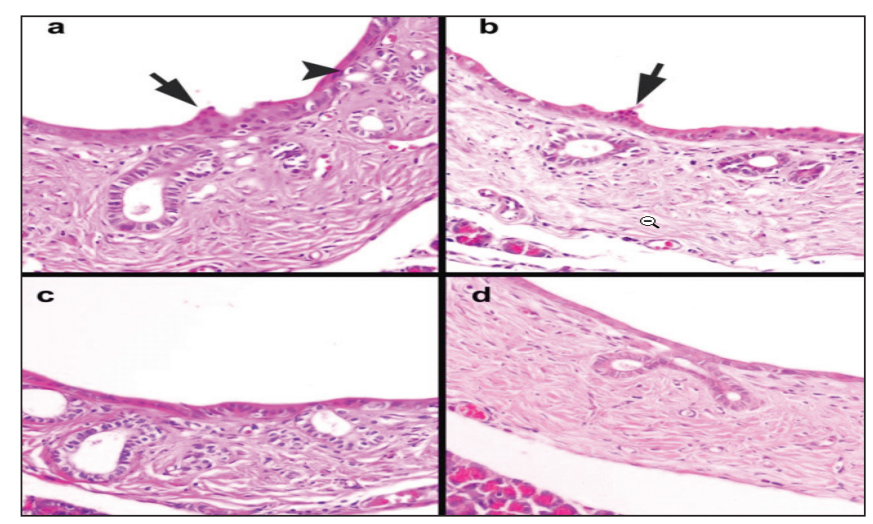

Fig. 1. Mild hyperplasia (arrow) and hydropic changes (arrowhead) in the bile duct epithelium. a) Group I, b) Group II, and c) Group III. Normal appearance of ductal and periductal structures in isotonic saline treatment group, d) Group IV. HE, 400x.

\section{Discussion}

The primary treatment of hydatid disease is surgery, which is unfortunately an invasive method with surgical trauma; morbidity and mortality rates and long hospital stay (Khuroo et al., 1997; Paksoy et al., 2005). All of the surgical and the invasive techniques used for treatment have the risk of hepatobiliary or intraperitoneal spillage of viable scolices. The application of scolicidal solution into the hydatid cyst is inevitable in order to avoid disseminating the parasite larvae during the procedure (Çaglar et al., 2008). Therefore, various scolicidal solutions have been used by experts to avoid secondary echinococcosis, to prevent likely recurrence, to inactivate parasites and to destroy the germinative membrane. In the literature, there is a serious debate about that scolicidal solutions such as formaldehyde, hypertonic saline, hydrogen peroxide, silver nitrate, cetrimide chlorheximide as well as ethyl alcohol may lead to caustic sclerosing cholangitis (Taranto et al., 1995; Kariv et al., 2002; Şahin et al., 2004). Sclerosing cholangitis is a serious complication that occurs because of the use of scolicidal solutions in the hepatobiliary system. So, an ideal solution should act as an effective scolicidal agent without local and systemic side effects.

Albendazole is the drug that is most widely used for the medical treatment of hydatid cyst disease. The efficacy of systemic administration of this drug is limited and prolonged exposure of albendazole to hepatobiliary system might cause milder biochemical and histopathological changes compared to hypertonic saline or $95 \%$ alcohol, but the effects of the albendazole on the biliary system does not exceed those of isotonic saline (Çaglar et al., 2008). In our study, albendazoleisotonic saline solution (Group II) mildly led to pathological damage in the liver and bile duct on 30th day. However, Erzurumlu et al. (1998) have indicated that albendazole has less toxicity on bile duct than the other agents. Higher scolicidal 
effect and lesser side-effects on the hepatobiliary system are the advantages of albendazole solution (Yetim et al., 2005). In contrast to other scolicidal agents, albendazole is not toxic to the liver and biliary structures in therapeutic doses. The caustic sclerosing cholangitis is a result of this toxicity as a well known complication of chemical scolicidal agents (Paksoy et al., 2005). On the other hand, a major problem with albendazole is that it has no liquid form. In surgical clinics, it was difficult to dissolve the albendazole tablets (Andazol, Biofarma) in sterilized water homogenously; even pure albendazole can not completely dissolved in normal saline. As albendazole is a lipophylic agent which is less soluble in normal saline, it is better to dissolve in absolute alcohol. In our experimental study, we used $2 \%$ absolute alcohol as a solvent for albendazole-normal saline scolicidal solution. We hypothesized that albendazole in $2 \%$ alcohol concentration could not cause the marked caustic damage to the epithelium of the communicating bile canaliculi. Albendazole concentration in our scolicidal solution is $20 \mu \mathrm{g} / \mathrm{ml} .10 \mu \mathrm{g} / \mathrm{ml}$ of albendazole solution is enough to completely kill scolices in vitro and the optimal concentration of albendazole for percutaneous injection and drainage is $1.7 \mu \mathrm{g} / \mathrm{ml}$. This solution has been shown to be ef- fective for treatment in both experimental and clinical studies (Paksoy et al., 2005; Yetim et al., 2005; Adaş et al., 2009). In the present study, we injected scolicidal agent directly into the common bile duct. Rats were sacrified on the 30th day after the administration of scolicidal solution. Differences in liver function tests in preoperative and postoperative period were not statistically significant between the control (Group IV) and study groups. Microscopic findings in the livers of Group III seem to be mild to moderate portal inflammation, single cell and hepatocellular necrosis (Table 4). Mucosal hyperplasia, hydropic changes and inflammation in the bile duct were lesser in Group III than in Group II (Table 5). Fibrosis was not observed in all groups.

In conclusion, albendazole in $2 \%$ alcohol solution did not cause more hepatobiliary damage than albendazole alone in isotonic saline application on the postoperative 30th day. The previous and present studies shows that "albendazole-alcohol-normal saline solution" may be used safely in the treatment of hydatid cysts as a scolicidal agent in experimental and clinic studies. Controlled randomized clinical studies are necessary for the routine use of this form of albendazole.

\section{REFERENCES}

Adaş, G., Arikan, S., Kemik, O., Oner, A., Sahip, N., Karatepe, O., 2009. Use of albendazole sulfoxide, albendazole sulfone, and combined solutions as scolicidal agents on hydatid cysts (in vitro study). World J. Gastroenterol. 15, 112-116.

Aggarwal, A.R., Garg, R.L., 1983. Formalin toxicity in hydatid liver disease. Anaesthesia. 38, 662-665.

Bilghiti, J., Benhamou, J.P., Houry, S., 1986.Caustic sclerosing cholangitis. Arch. Surg. 121, 1162-1165.

Çaglar, R., Yuzbasıglu, M.F., Bulbuloglu, E., Gul, M., Ezberci, F., Kale, I.T., 2008. In vitro effectiveness of different chemical agents on scolices of hydatid cysts. J. Invest. Surg. 21, 71-75.

Eckert, J., Gemmel, M.A., Soulsby, E.J.I., Matya, Z., 1982. Echinococcosis/hydatidosis, surveillance, prevention and control: fao/unep/who guidelines.Food and agriculture organization of the United Nations.

Erzurumlu, K., Tezelman, S., Çevikbaş, U., Eldegez, U., 1990. Sklerozan kolanjit etiyolojisinde Skolosidal solüsyonların etkileri. Ulusal Cerrahi Dergisi. 6, 22-26.

Erzurumlu, K., Hokelek, M., Baris, S., Sahin, M., Birinci, A., Amanvermez, R., Tac, K., 1998. Effect of albendazole sulfoxide solution on the scolices and the hepatobiliary system. Eur. Surg. Res. 30, 433-438.

Eyüpoğlu, B., Doğanay, M., Reis, E., Yüksel, Y.N., Kulaçoğlu, S., Aydın, K.N., 1999. The effects of scolicidal agents on hepatopancreaticobiliary system "An experimental study”. Turkish J. Gastroenterol. 10, 280-286.

Karavias, D.D., Vagianas, C.E., Kakkos, S.K., Panaqopoulis, C.M., 1996. Peritoneal echinococcosis. World J. Surg. 20, 337-340.

Kariv, R., Konikoff, F.M., 2002. Sclerosing cholangitis - primary, secondary and more. I.M.A.J. 4, 1141-1142.

Khuroo, M.S., Wani, N.A., Javid, G., Khan, B.A., Yattoo, G.N., Shah, A.H., Jeelani, S.G., 1997. Percutaneus drainage compared with surgery for hepatic hydatid cysts. N. Engl. J. Med. 337, 881-887.

Kozak, O., Atak, M., Gülec, B., 2000. The effects of scolicidal solutions to liver and biliar tract. Gülhane Medical Journal. 42, $269-275$.

Montera, J.V.M., Garcia, J.A., Lafuenta, J.P., 1996. Fat-fluid level in hepatic hydatid cysts: A new sign of rupture into the biliary tree? A.J.R. $167,91-94$.

Paksoy, Y., Odev, K., Sahin, M., Arslan, A., Koc, O., 2005. Percutaneous treatment of liver hydatid cysts: Comparision of direct injection of albendazole and hypertonic saline solution. A.J.R. 185, 727-733.

Sezer, A., Hatipoglu, A.R., Usta, U., Altun, G., Sut, N., 2010. Effects of intraperitoneal melatonin on caustic sclerosing cholangitis due to scolicidal solution in a rat model. Curr. Ther. Res. 71, 118-128.

Şahin, M., Eryilmaz, R., Bulbuloglu, E., 2004. The effect of scolicidal agents on liver and biliary tree (experimental study). J. Invest. Surg. 17, 323-326.

Taranto, D., Beneduce, F., Vitale, L.M., Loguercio, C., Del Vecchio Blanco, C., 1995. Chemical sclerosing cholangitis after injection of scolicidal solution.Ital. J. Gastroenterol. 27, 78-79.

Yetim, I., Erzurumlu, K., Hokelek, M., Barıs, S., Dervisoglu, A., Polat, C., Belet, U., Buyukkarabacak, Y., Guvenli, A., 2005. Results of alcohol and albendazole injections in hepatic hydatidosis: Experimental study. J. Gastroenterol. Hepatol. 20, 1442-1447. 